\title{
PENGARUH KESELAMATAN KERJA DAN KESEHATAN KERJA TERHADAP KINERJA KARYAWAN PT. LINGGA TIGA SAWIT KABUPATEN LABUHANBATU
}

\author{
Wirna Juniati Hasibuan ${ }^{1}$, Zuriani Ritonga ${ }^{2}$ \\ ${ }^{1}$ Alumni Sarjana Ekonomi STIE Labuhanbatu \\ ${ }^{2}$ Dosen STIE Labuhanbatu
}

\begin{abstract}
ABSTRAK
Tujuan Penelitian ini adalah untuk mengetahui seberapa besar pengaruh keselamatan dan kesehatan kerja terhadap kinerja karyawan PT. Lingga Tiga Sawit Labuhanbatu. Jumlah anggota populasi sebanyak 181 orang karyawan. Teknik pengambilan sampel menggunakan simple random sampling karena pengambilan sampel anggota populasi dilakukan secara acak tanpa memperhatikan strata yang ada dalam populasi tersebut. Dan penentuan ukuran sampel dalam penelitian ini menggunakan rumus Slovin, sehingga diperoleh hasil sebanyak 64 responden yang akan dijadikan sampel dalam penelitian. Penelitian ini menggunakan analisis deskriptif dengan pendekatan kuantitatif yang menggunakan kuesioner sebagai alat pengumpulan data dan menggunakan teknik analisis regresi linear sederhana untuk mengukur pengaruh dari variabel bebas terhadap variabel terikat yaitu keselamatan dan kesehatan kerja sebagai variabel independent $(\mathrm{X})$ dan kinerja karyawan sebagai variabel dependent (Y). Pengolahan data dalam penelitian ini dibantu dengan program Stastitical for Product and Service Solution (SPSS) versi 19. Hasil penelitian ini menyatakan bahwa keselamatan dan kesehatan kerja berpengaruh signifikan dan positif terhadap kinerja karyawan PT.Lingga Tiga Sawit Labuhanbatu. Berdasarkan hasil pengujian empiris variabel keselamatan dan kesehatan kerja memiliki nilai koefisien sebesar 0.461 dengan nilai t hitung 3.477 serta nilai signifikansi 0.001 .
\end{abstract}

\section{Kata Kunci: Keselamatan dan Kesehatan Kerja, Kinerja Karyawan}

\section{Pendahuluan}

Sumber daya manusia merupakan peranan penting bagi keberhasilan suatu organisasi atau perusahaan, karena manusia merupakan aset hidup yang perlu dipelihara dan dikembangkan. Oleh karena itu karyawan harus mendapatkan perhatian yang khusus dari perusahaan. Kenyataan bahwa manusia sebagai aset utama dalam organisasi atau perusahaan, harus mendapatkan perhatian serius dan dikelola dengan sebaik mungkin. Hal ini dimaksudkan agar sumber daya manusia yang dimiliki perusahaan mampu memberikan kontribusi yang optimal dalam upaya pencapaian tujuan organisasi. Dalam pengelolaan sumber daya manusia inilah diperlukan manajemen yang mampu mengelola sumber daya secara sistematis, terencana, dan efisien. Salah satu hal yang harus menjadi perhatian utama bagi manajer sumber daya manusia ialah sistem keselamatan dan kesehatan kerja.

Keselamatan dan kesehatan kerja termasuk salah satu program pemeliharaan yang ada di perusahaan. Pelaksanaan program keselamatan dan kesehatan kerja bagi karyawan sangatlah penting karena bertujuan untuk 
menciptakan sistem keselamatan dan kesatuan kerja dengan melibatkan unsur manajemen, tenaga kerja, kondisi dan lingkungan kerja yang terintegrasi dalam rangka mengurangi kecelakaan.

\section{Landasan Teori}

\section{Penelitian Terdahulu}

Beberapa penelitian yang telah dilakukan oleh para peneliti sebelumnya yang dianggap ada relevansinya dengan penelitian yang dilakukan oleh penulis antara lain adalah penetitian yang dilakukan Fahmawati dan Batu Bara. Fahmawati (2005), meneliti dengan judul "Pengaruh Kesehatan dan Keselamatan Kerja (K3) Terhadap Kinerja Karyawan pada PT. Cahaya Surya Tunas Tapioka ". Hasil uji $\mathrm{F}$ sebesar 24,120 menunjukkan bahwa kesehatan dan keselamatan kerja serta lingkungan kerja mempunyai pengaruh yang signifikan terhadap kinerja karyawan sebesar, hasil uji t sebesar 4,260 menunjukkan bahwa Kesehatan dan Keselamatan Kerja berpengaruh signifikan terhadap kinerja karyawan sebesar dan hasil uji t untuk sebesar 4,98 menunjukkan bahwa lingkungan kerja berpengaruh signifikan terhadap kinerja karyawan dan koefisien determinan sebesar 0,556 menunjukkan bahwa variabel bebas (kesehatan dan keselamatan kerja serta lingkungan kerja) dapat menjelaskan 56,6 \% terhadap variabel terikat (kinerja karyawan).

Khaerurahman (2007) meneliti dengan judul "Pengaruh Kesehatan dan Keselamatan Kerja (K3) Terhadap Kinerja Karyawan Pada PT. Sinar Sosro Cabang". Hasil uji F menunjukkan bahwa kesehatan dan keselamatan kerja mempunyai pengaruh yang signifikan terhadap kinerja karyawan sebesar 19,642 dan hasil uji $t$ menunjukkan bahwa keselamatan kerja berpengaruh signifikan terhadap kinerja karyawan sebesar 2,882 terhadap kinerja karyawan, dan kesehatan kerja mempunyai pengaruh signifikan terhadap kinerja sebesar 3,136 koefisien determinasi ( $\mathrm{R}$ square) sebesar 0,40 menunjukkan bahwa variabel bebas (Kesehatan dan Keselamatan Kerja) dapat menjelaskan $40 \%$ terhadap variabel terikat (Kinerja Karyawan).

\section{Pengertian Keselamatan Kerja dan Program Keselamatan Kerja}

Keselamatan kerja menurut Mondy dan Noe (2005:360) adalah perlindungan karyawan dari luka-luka yang disebabkan oleh kecelakaan yang terkait dengan pekerjaan. Resiko keselamatan merupakan aspek-aspek dari lingkungan kerja yang dapat menyebabkan kebakaran, ketakutan aliran listrik, terpotong, luka memar, keseleo, patah tulang, kerugian alat tubuh, penglihatan dan pendengaran. Kesehatan kerja adalah kebebasan dari kekerasan fisik. Resiko kesehatan merupakan faktorfaktor dalam lingkungan kerja yang bekerja melebihi periode waktu yang ditentukan, lingkungan yang dapat membuat stres emosi atau gangguan fisik.

Pengertian program keselamatan kerja menurut Mangkunegara (2006:161) Keselamatan kerja menunjukkan pada kondisi yang aman atau selamat dari penderitaan, kerusakan atau kerugian di tempat kerja. Keselamatan kerja adalah keselamatan yang berkaitan dengan mesin, pesawat, alat kerja, bahan dan proses pengolahannya, landasan tempat kerja dan lingkungannya serta cara-cara melakukan pekerjaan.

\section{Pengertian Kesehatan kerja dan Program Kesehatan Kerja}

Program kesehatan kerja merupakan suatu hal yang penting dan perlu diperhatikan oleh pihak pengusaha. 
Karena dengan adanya program kesehatan yang baik akan menguntungkan para karyawan secara material, karena karyawan akan lebih jarang absen, bekerja dengan lingkungan yang lebih menyenangkan, sehingga secara keseluruhan karyawan akan mampu bekerja lebih lama. Pengertian program kesehatan kerja: Menurut

Mangkunegara (2011:161) "Program kesehatan kerja menunjukkan pada kondisi yang bebas dari gangguan fisik, mental, emosi atau rasa sakit yang disebabkan oleh lingkungan kerja. Resiko kesehatan merupakan faktor-faktor dalam lingkungan kerja yang bekerja melebihi periode waktu yang ditentukan, Lingkungan yang dapat membuat stress emosi atau gangguan fisik".

\section{Tujuan dan Manfaat Keselamatan dan Kesehatan Kerja \\ Menurut \\ Mangkunegara}

(2005:165) bahwa tujuan dan manfaat dari keselamatan dan kesehatan kerja adalah sebagai berikut:

a. Agar setiap pegawai mendapat jaminan keselamatan dan kesehatan kerja yang baik secara fisik, sosial, dan psikologis.

b. Agar setiap perlengkapan dan peralatan kerja digunakan sebaikbaiknya seselektif mungkin.

c. Agar semua hasil produksi dipelihara keamanannya.

d. Agar adanya jaminan atas pemeliharaan dan peningkatan kesehatan gizi pegawai.

e. Agar meningkatkan kegairahan, keserasian kerja, dan partisipasi kerja.

f. Agar terhindar dari gangguan kesehatan yang disebabkan oleh lingkungan atau kondisi kerja. g. Agar setiap pegawai merasa aman dan terlindungi dalam bekerja.

Tujuan dan manfaat dari keselamatan dan kesehatan kerja ini tidak dapat terwujud dan dirasakan manfaatnya, jika hanya bertopang pada peran tenaga kerja saja tetapi juga perlu peran dari pimpinan.

\section{Kerangka Konseptual}

Pengalaman kerja merupakan suatu hal yang penting dalam suatu hal yang penting dalam setiap perusahaan, baik itu dalm perusahaan maupun dalam sektor informal. Karena dengan pengalaman kerja, maka pekerjaan akan dapat berjalan dengan lancar. Semakin lancar suatu usaha mengakibatkan usaha tersebut mengalami kemajuan dan perkembangan. Maka seorang pegawai yang mempunyai pengalaman kerja yang tinggi dapat meningkatkan prestasi kerja atau kinerja perusahaan, sehingga semua pekerjaan dapat berjalan dengan baik.

Kesehatan kerja dan Keselamatn kerja dalam penulisan ini skripsi ini merupakan variabel bebas yang mempengaruhi variabel kinerja karyawan. Jadi keselamatan kerja dan kesehatan kerja merupakan suatu kondisi yang harus selalu diperhatikan dalam mencapai tujuan perusahaan. Keselamatan kerja (X1), dan Kesehatan kerja (X2) merupakan variabel bebas (independent variable). Sedangkan prestasi kerja (Y) merupakan variabel terikat (dependent variable). Pada penelitian ini akan menguji atau mencari adanya pengaruh yang positif, signifikan antara variabel bebas dengan variabel terikat. 


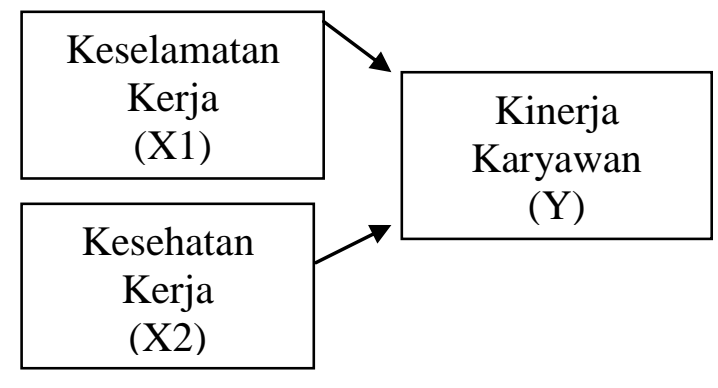

Gambar

Kerangka Konseptual

\section{Metode Penelitian}

\section{Populasi dan Sampel Penelitian}

Populasi

Menurut Sugiyono (2007:72)

Populasi adalah wilayah generalisasi yang terdiri dari objek atau subjek yang mempunyai kualitas dan karakteristik tertentu. Kesimpulannya, populasi bukan hanya orang tetapi benda-benda alam yang lain. Populasi juga bukan jumlah yang ada pada objek yang dipelajari tetapi juga meliputi karakteristik atau sifat maupun pengukuran, baik secara kualititatif maupun kuantitatif daripada karakteristik tertentu mengenai sekelompok objek yang jelas dan lengkap. Tujuan diadakan populasi yaitu agar dapat menentukan besarnya anggota sampel yang diambil dari anggota sampel dan membatasi berlakunya daerah generalisasi. Pada pen elitian ini populasinya adalah seluruh karyawan PT.Lingga Tiga Sawit Labuhanbatu sebanyak 39 orang karyawan.

\section{Sampel Penelitian}

Menurut Sugiyono (2007:73-74) Sampel adalah bagian dari jumlah dan karakteristik yang dimiliki oleh populasi tersebut. Teknik pengambilan sampel dalam penelitian ini adalah teknik probability sampling yaitu teknik sampling yang memberikan peluang yang sama bagi setiap unsur populasi untuk dipilih menjadi anggota sampel. Yang meliputi simple random sampling karena pengambilan sampel anggota populasi dilakukan secara acak tanpa memperhatikan strata yang ada dalam populasi tersebut, maka peneliti mengambil dari jumlah populasi atau sebanyak 39 orang.

\section{Skala Pengukuran}

Untuk mendapatkan data-data yang berkaitan dengan kesehatan dan keselamtan kerja dan kinerja diguanakn instrumetn berupa kuesioner dengan pengukuran mengunakan skala likert yang mempunya lima tingkatan yang merupakan skala jenis ordinal. Dengan menggunakan dua instrument, yaitu keselamatan \& kesehatan kerja, dan kinerja yang kemudian dikembangkan menjadi beberapa pertanyaan atau parameter yang akan diukur.

$\begin{array}{ll}\text { Sangat Setuju (SS) } & =\text { skor } 5 \\ \text { Setuju (S) } & =\text { skor } 4 \\ \text { Netral (N) } & =\text { skor } 3 \\ \text { Tidak Setuju (TS) } & =\text { skor } 2 \\ \text { Sangat Tidak Setuju (STS) } & =\text { skor } 1\end{array}$

\section{Teknik Pengumpulan data}

Teknik pengambilan data yang digunakan dalam penelitian ini adalah sebagai berikut:

1. Wawancara (interview)

Menurut I Made Wirartha (2006) wawncara adalah salah satu metode pengumpulan data dengan jalan komunikasi, yaitu melalui kontak atau hubungan pribadi antara pengumpul data (pewawamcara) dengan sumber data responden. Wawancara dalam meneliti ini mengacu pada pertanyaan-pertanyaan yang berkaitan dengan penerapan sanksi administratif pengembalian bahan 
pustaka.

Wawancara yang dilakukan menggunakan wawancara tidak terstruktur karena hanya ingin mendapatkan informasi tambahan atau garis besar permasalahan dari garis besar permasalahan dari responden yang telah mengisi kuesioner. Seperti yang dinyatakan oleh Sugiono (2012) wawancara tidak berstruktur adalah wawancara bebas dimana peneliti tidak menggunakan pedoman wawancara yang telah tersusun secara sistematis dan lengkap untuk pengumpulan datanya.

2. Penelitian Kepustakaan (Library Research)

Pada tahap ini, penulis berusaha untuk memperoleh berbagai informasi sebanyak-banyaknya untuk dijadikan sebagai dasar teori dan acuan untuk mengolah data dengan cara membaca, mempelajari, menelaah, dan mengkaji literatur-literatur berupa buku-buku, jurnal, makalah, maupun penelitianpenelitian terdahulu yang berkaitan dengan masalah yang diteliti.

3. Riset Internet

Pengumpulan data berasal dari situssitus terkait untuk memperoleh tambahan literatur, jurnal, dan dat lainnya.

\section{Hasil Penelitian Dan Pembahasan Hasil Deskriptif Responden}

Untuk mengetahui reaksi karyawan pada pengaruh keselamatan dan kesehatan kerja yang diberikan perusahaan terhadap kinerja karyawan, maka peneliti menyebarkan kuesioner kepada 39 orang karyawan yang menjadi sampel dalam penelitian ini.

\section{Uji Validitas}

Uji Validitas digunakan untuk mengukur derajat ketepatan dalam setiap item pertanyaan suatu kuesioner, pertanyaan-pertanyaan dalam kuesioner dapat dikatakan valid apabila pertanyaan tersebut mampu mengungkapkan sesuatu yang akan diukur oleh kuesioner tersebut dan apabila nilai korelasi hitung ( $\mathrm{r}$ hitung) lebih besar daripada nilai korelasi tabelnya ( $\mathrm{r}$ tabel). Nilai $\mathrm{r}$ hitung adalah nilai-nilai yang berada dalam kolom "Correlations" pada lembar output spss. Apabila nilai kolom total correlations $>\mathrm{r}$ tabel, maka item pertanyaan tersebut dapat dikatakan valid.

\section{Uji Reliabilitas}

Uji Reliabilitas adalah indeks yang menunjukkan sejauh mana alat pengukur dapat diandalkan. Uji reliabilitas digunakan untuk mengukur ketetapan atau kejituan suatu instrumen. Kuesioner dapat dikatakan reliabel (andal) jika nilai $r$ alpha positif dan $r$ alpha $>0,6$, artinya butir pertanyaan atau variabel tersebut adalah dapat dipercaya (reliabel).

\section{Hasil Uji Reliabilitas}

\begin{tabular}{|c|l|c|l|}
\hline No & \multicolumn{1}{|c|}{ Variabel } & \multicolumn{1}{|c|}{ Alpha } & \multicolumn{1}{|c|}{ Ket } \\
\hline 1 & $\begin{array}{l}\text { Keselamatan dan } \\
\text { Kesehatan Kerja } \\
(\mathrm{X})\end{array}$ & 0,841 & $\begin{array}{l}\text { Reliabe } \\
1\end{array}$ \\
\hline 2 & $\begin{array}{l}\text { Kinerja Karyawan } \\
(\mathrm{Y})\end{array}$ & 0,880 & $\begin{array}{l}\text { Reliabe } \\
1\end{array}$ \\
\hline
\end{tabular}

Sumber:

Diolah dari data kuesioner yang terlampir pada lampiran

Berdasarkan Tabel diatas terlihat bahwa nilai alpha dari variabel $\mathrm{X}$ dan variabel Y lebih besar dari 0,6. Hal ini berarti data yang digunakan telah layak untuk digunakan pada analisis selanjutnya. 


\section{Pembahasan}

Berdasarkan analisis frekuensi responden yang telah dilakukan, didapatkan hasil mengenai tanggapan responden terhadap variabel keselamatan dan kesehatan kerja. Variabel keselamatan dan kesehatan kerja harus dapat memenuhi indikator membuat kondisi kerja yang aman, pendidikan dan pelatihan keselamatan dan kesehatan kerja, penciptaan lingkungan kerja yang sehat, pelayanan kebutuhan karyawan, serta pelayanan Kesehatan. Dari analisis frekuensi tersebut, telah didapatkan kesimpulan hasil bahwa bahwa 20 orang responden $(55,5 \%)$ setuju akan Pertanyaan kondisi kerja yang aman pada perusahaan, pendidikan dan pelatihan keselamatan dan kesehatan kerja, kemudian dari 10 orang responden $(27,8 \%)$ berpendapat setuju mengenai penciptaan lingkungan kerja yang sehat, pelayanan kebutuhan dan pelayanan kesehatan.

Hasil analisis frekuensi terhadap variabel dependen yaitu kinerja karyawan, dapat diketahui dari hasil jawaban bahwa sebanyak $61,1 \%$ karyawan yang telah menerapkan prinsip kinerja dalam melaksanakan pekerjaannya. Hal tersebut didasarkan dari indikator kinerja yaitu kualitas kerja, kuantitas kerja, jangka waktu pekerjaan, kehadiran di tempat kerja. Dari kesimpulan analisis frekuensi terhadap kedua variabel tersebut, dapat diketahui bahwa terdapat hubungan antara keselamatan \& kesehatan kerja dan kinerja karyawan. Diantaranya peralatan untuk menghindari kecelakaan, lingkungan kerja aman bersih, serta jaminan sosial yang diberikan dapat mempengaruhi kinerja karyawan.

Berdasarkan tabel 4.24 nilai koefisien determinasi $R$ Square sebesar
0,163 menunjukkan bahwa 16,3\% peningkatan kinerja karyawan dipengaruhi oleh keselamatan dan kesehatan kerja, sedangkan sisanya $83,7 \%$ (100\%-16,3\%) dipengaruhi oleh variabel lain yang tidak diukur dalam penelitian ini. Kemudian pada tabel 4.25 hasil dari perhitungan menunjukkan bahwa koefisien regresi (beta) variabel keselamatan dan kesehatan kerja terhadap kinerja karyawan adalah sebesar 0,461. Angka ini bernilai positif, artinya kedua variabel tersebut memiliki hubungan yang searah. Ini menunjukkan bahwa kinerja karyawan PT. Lingga Tiga Sawit Labuhanbatu dipengaruhi oleh keselamatan dan kesehatan kerja. Semakin baik program keselamatan dan kesehatan kerja yang diberika perusahaan, maka kinerja karyawan akan semakin meningkat. Hasil F Test menunjukkan bahwa F hitung adalah 12,089 lebih besar dari $F$ tabel 4,00 artinya signifikan, dengan tingkat signifikansi 0,001 yang lebih kecil dari $(<0,05)$ berarti keselamatan dan kesehatan kerja berpengaruh positif dan signifikan terhadap kinerja karyawan.

\section{Kesimpulan Dan Saran Kesimpulan}

Dari uraian dan pembahasan pada bab-bab sebelumnya berkaitan dengan seberapa besar pengaruh keselamatan dan kesehatan kerja terhadap kinerja karyawan PT.Lingga Tiga Sawit Labuhanbatu, maka dapat ditarik kesimpulan sebagai berikut:

Berdasarkan analisis regresi sederhana yang dilakukan maka dapat diperoleh persamaan regresi adalah $\mathrm{Y}=$ $19,835+0,461 X$. Hal ini menunjukkan bahwa variabel $\mathrm{x}$ yakni keselamatan dan kesehatan kerja berpengaruh signifikan terhadap kinerja karyawan PT. Lingga 
Tiga Sawit Labuhanbatu. signifikan dibuktikan dari nilai $\mathrm{F}$ hitung $=12,089$. yang artinya signifikan karena lebih besar dari $F$ tabel $=4,00$. Dengan tingkat signifikansi 0,001 yang jauh lebih kecil dari $(<0,05)$ berarti keselamatan dan kesehatan kerja berpengaruh positif dan signifikan terhadap kinerja karyawan.

Kemudian nilai koefisien determinasi $R$ Square sebesar 0,163 menunjukkan bahwa $16,3 \%$ peningkatan kinerja karyawan dipengaruhi oleh keselamatan dan kesehatan kerja, sedangkan sisanya 83,7\% (100\%-16,7\%) dipengaruhi oleh variabel lain yang tidak diukur dalam penelitian ini misalnya pendidikan dan pelatihan, gaya kepemimpinan, dan kompensasi.

\section{Saran} telah diuraikan, maka saran atau rekomendasi yang dapat diberikan sehubungan dengan judul yaitu pengaruh keselamatan dan kesehatan kerja terhadap kinerja karyawan PT.Lingga Tiga Sawit Labuhanbatu adalah sebagai berikut:

Perusahaan

harus

mempertahankan keselamatan dan kesehatan kerja yang ada pada perusahaan dan telah diterapkan selama ini, agar kinerja karyawan tetap berada pada tingkat yang tinggi. Dan perusahaan harus senantiasa menyediakan alat pelindung diri menurut ketentuan batas waktu agar selalu dalam kondisi layak pakai sehingga dapat melindungi karyawan dan mencegah kejadian yang tidak diinginkan. Kemudian departemen

keselamatan dan kesehatan kerja (HSE) harus secara berkala memberikan pelatihan dan pendidikan mengenai sistem prosedur kerja, audit keselamatan, pemakaian alat pelindung diri, sistem inspeksi dan pemeliharaan peralatan. Hal ini yang paling penting ialah menciptakan kesadaran yang tinggi kepada semua karyawan terhadap pentingnya keselamatan dan kesehatan kerja. Kesadaran yang dimiliki setiap karyawan mampu mendukung tercapainya tujuan program keselamatan dan kesehatan kerja di perusahaan yaitu mencegah dan mengurangi kecelakaan akibat kerja. Kesadaran dari para pekerja tentang keselamatan dan kesehatan kerja harus ditingkatkan karena pada umumnya kecelakaan-kecelakaan kerja yang terjadi adalah faktor kelalaian pekerja itu sendiri.

Dan perusahaan perlu memberikan sanksi yang tegas kepada karyawan yang melanggar aturan-aturan keselamatan dan kesehatan kerja. Hal ini dimaksudkan agar karyawan lebih disiplin dan juga untuk menghindari terjadinya kecelakaan atau kerusakan akibat kerja.

\section{Daftar Pustaka}

Mathis, Robert L. \& Jackson. John H. 2005. Manajemen Sumber Daya Manusia. Jakarta: Penerbit Salemba Empat.

Mangkunegara, DR. A.A. Anwar Prabu. 2005. Evaluasi Kinerja SDM. Bandung: Penerbit Refika Aditama.

Mondy, R. Wayne. \& Noe, Robert M. 2005. Human Resources Management, Edisi ke-9. New Jersey: Penerbit Prentice Hall.

Sunyoto, Drs. Danang. 2012. Manajemen Sumber Daya Manusia. Yogyakarta: Penerbit CAPS.

Handoko, T. Hani. 2007. Manajemen Personalia dan Sumberdaya Manusia. Yogyakarta: Penerbit BPFE.

Dessler, Gary. 2006. Manajemen Sumber Daya Manusia. Edisi ke-10. Jilid 2. Jakarta: Penerbit Indeks. 
Ranupandojo, Hedjrachman, \& Suad, Husnan. 2006. Manajemen Personalia, Edisi Ke-4. Yogyakarta: Penerbit BPFE.

Gomes, Faustino Cardoso. 2006. Manajemen Sumber Daya Manusia. Yogyakarta: Penerbit Andi.

Rivai, Veithzal. 2005. Manajemen Sumber Daya Manusia Untuk Perusahaan. Jakarta: Penerbit Raja Grafindo Persada Sugiyono, Prof. Dr. 2007. Metode Penelitian Bisnis. Bandung: Penerbit Alfabeta 